\title{
ワークショップ 4
}

\section{WS4-1}

\section{ヒト悪性腫瘍におけるマクロファージの役割一がん免疫との接点}

菰原義弘, 大西紘二, 藤原章雄, 竹屋元裕

(熊本大学大学院生命科学研究部 細胞病理学分野)

ヒトの固形癌の進展において，多くの局面でマクロファージが関与すると考えられている，腫瘍内 に浸潤したマクロファージは, TAM（tumor-associated macrophage）と呼ばれ, 腫瘍の増殖や転移, 浸潤, 血管新生, 免疫抑制に関与している。TAM の多くは血液単球に由来し, 腫瘍細胞由来の CCL2（MCP1） や GM-CSF, M-CSF により腫瘍局所へ遊走してくる。腫瘍局所では腫瘍由来因子や低酸素状態などによ りマクロファージは M2 寄りの活性化状態に誘導され，腫瘍の進展に寄与しているようである，その ためマクロファージを標的にした治療法の開発も試みられている。また，リンパ節は免疫反応に重要 な役割を果たす臟器であり, 多数の在住マクロファージが認められる. 所属リンパ節におけるマクロファー ジは, 癌病変部から流入する腫瘍抗原を取り込み, リンパ球に抗原提示することで抗腫瘍免疫の一翼 を担っているようである.TAM やリンパ節マクロファージなどの役割や治療標的としての可能性につ いて考察を加えたい. 